\title{
DRAGONFLIES AND DAMSELFLIES (INSECTA: ODONATA) OF THE NORTHEASTERN REGION OF BANGLADESH WITH FIVE NEW ADDITIONS TO THE ODONATA FAUNA OF BANGLADESH
}

\section{Kawsar Khan}

Department of Biochemistry and Molecular Biology, School of Life Sciences, Shahjalal University of Science and Technology, Sylhet 3114, Bangladesh

kawsarkhan-bmb@sust.edu

Abstract: Odonata were surveyed in one reserve forest, two nationa parks, one Eco Park, one lake and one University campus in the northeastern region of Bangladesh from March 2014 to March 2015 A total of 64 species of Anisoptera and Zygoptera belonging to 41 genera under seven families were recorded. Among them 45 species and 19 genera were new records for the study area. Two species of Anisoptera, i.e., Anax indicus Lieftinck, 1942 and Gynacantha khasiaca MacLachlan, 1896, and three species of Zygoptera i.e., Matrona nigripectus Selys, 1879, Agriocnemis kalinga Nair \& Subramanian, 2014, and Prodasineura laidlawii Forster, 1907 were recorded for the first time from Bangladesh.

Keywords: Agriocnemis kalinga, Anax indicus, Anisoptera, Bangladesh, Gynacantha khasiaca, Matrona nigripectus, Odonata diversity, Prodasineura laidlawii, Zygoptera.
Odonata (dragonflies and damselflies) are gorgeous aquatic insects distributed throughout the world. Odonates are highly specific to their niche, depend heavily on water bodies for feeding and breeding and are extremely sensitive to the alteration of the locale (Crowley \& Johnson 1982; Butler 2008; Silva et al. 2010). Hence, dragonflies and damselflies are considered indicators of wetland health. Besides, they are important elements of the food chain; many birds feed on them while odonates predate on other small insects like mosquitoes, moths, butterflies and conspecific and heterospecific Odonata (Cheshire et al. 2005). Till date, 6050 species of Odonata belonging to 600 genera have been recorded throughout the World (Vick 2002).

Bangladesh possess an enormus area of wetlands including rivers, lakes and ponds. Moreover, in monsoon heavy rainfall creates many temporary water bodies which hold water for more than three months. The
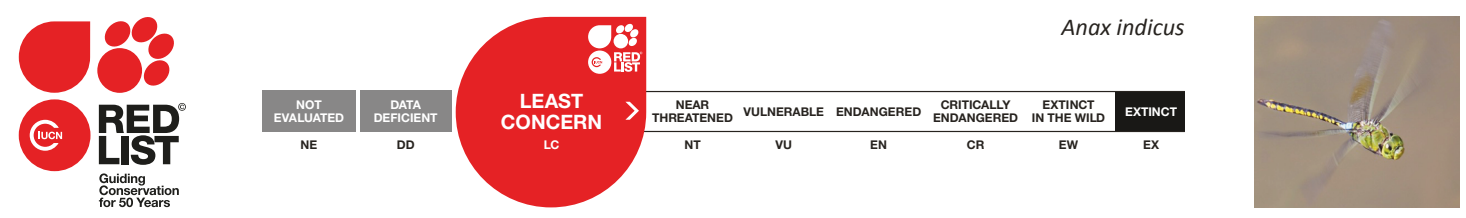

DOI: http://dx.doi.org/10.11609/JoTT.04314.7795-804 | ZooBank: urn:Isid:zoobank.org:pub:EA802823-1246-4D24-AE8A-EE20084781AC

Editor: K.A. Subramanian, Zoological Survey of India, Kolkata, India.

Date of publication: 26 September 2015 (online \& print)

Manuscript details: Ms \# 04314 | Received 11 April 2015 | Finally accepted 07 August 2015

Citation: Khan, M.K. (2015). Dragonflies and damselflies (Insecta: Odonata) of the northeastern region of Bangladesh with five new additions to the Odonata fauna of Bangladesh. Journal of Threatened Taxa 7(11): 7795-7804; http://dx.doi.org/10.11609/JoTT.04314.7795-804

Copyright: (c) Khan 2015. Creative Commons Attribution 4.0 International License. JoTT allows unrestricted use of this article in any medium, reproduction and distribution by providing adequate credit to the authors and the source of publication.

Funding: Self funded.

Conflict of Interest: The author declares no competing interests.

Acknowledgement: I am very thankful to Noppadun Makbun, Shantanu Joshi and K.A. Subramanian for their help in identifying a few species and in preparing the manuscript. I am also thankful to Shafique Haider Chowdhury who helped with the research articles and gave valuable suggestions during the study period. I am also thankful to Junaeed Ahmed and Md Saiful Islam for their help during manuscript preparation. 
temporary water resources can act as breeding places for many Odonata species (Chowdhury \& Mohiuddin 1994). In addition to those permanent and temporary stagnant wetlands, a good number of waterfalls and streams exist, particularly in the north-east and the south-east part of the country. This diverse range of water bodies along with many tropical forest patches has generated a suitable habitat for many Odonata species. Despite that ambient milieu, ironically, scanty research has been carried out to document the Odonata fauna of Bangladesh (Begum et al. 1977; Biswas et al. 1980; Chowdhury \& Akhteruzzaman 1983; Chowdhury \& Miah 1989; Chowdhury \& Mohiuddin 1993; Nomura \& Alam 1995; Khan 2015). The most comprehensive work was carried out by Chowdhury \& Mohiuddin (2011), where the researchers had documented 96 species of Odonata from the eastern region of Bangladesh.

The northeastern region of Bangladesh is administratively under Sylhet division. The division covers more than $12,636 \mathrm{sq} . \mathrm{km}$. and consists of four districts (Sylhet, Maulavibazar, Sunamgong and Habigonj) which are surrounded by the Indian states of Meghalaya, Tripura and Assam. This naturally enriched region contains four protected areas, i.e., Lawachara National Park, Satchari National Park, Khadimnagor National Park and Rema-Kalenga Wildlife Sanctuary; three eco parks, i.e., Madhabkunda Eco Park, Tilagar Eco Park and Borshijora Eco Park. Also, the northeastern region is well known for its large lakes-Tanguar Haor, Hakaluki Haor, Baikkar Bill; rivers-Surma, Kushiara, Kalindi and Khoai; waterfalls-Madhobkunda and Hamham. Previously, a total of 31 species of Odonata of which 17 species of dragonflies and 14 species of damselflies were recorded from the area (Chowdhury \& Mohiuddin 2011). The present study have added 45 species new to this region of which five species are recorded for the first time from Bangladesh. The present paper also updates the checklist diversity, distribution and status of Odonata in the northeastern region.

\section{MATERIALS AND METHODS \\ Study area}

The study was carried out in six different areas of the northeastern region (administratively under Sylhet division) from March 2014 to March 2015 (Fig. 1). The study area includes two national parks, i.e.,

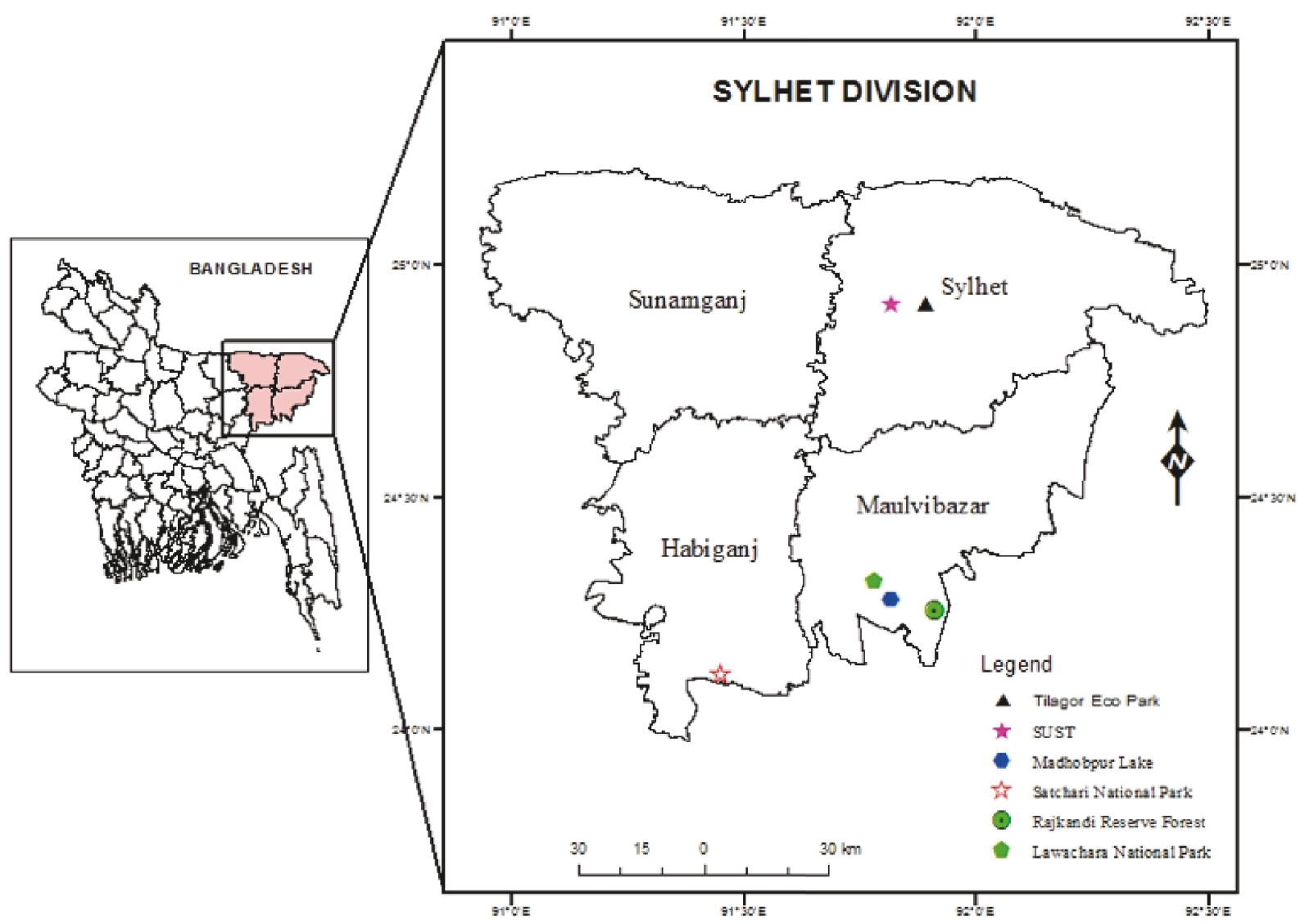

Figure 1. A reference map of the north east region (Sylhet division) of Bangladesh with the highlighted study area 
Lawachara National park of Maulavibazar District and Satchari National Park of Habigonj District. The survey was also carried out in Rajkandi Reserve Forest and Tilagor Eco Park. Also, an extensive survey was carried out in Shahjalal University of Science and Technology (SUST) campus of Sylhet District and one opportunistic survey was executed in Madhobpur Lake. The average temperature of these study areas varies from $10-36{ }^{\circ} \mathrm{C}$.

\section{Sampling of odonates}

The odonates were surveyed by walking opportunistically through the forest paths, near streams, lakes, ponds and grasslands associated with the wetlands from $08.00-17.00 \mathrm{hr}$. The specimens were photographed for various identification features by Canon 600D camera using 55-250 mm lens. Voucher specimens were collected, wherever possible, using insect sweeping net and deposited in the Department of Biochemistry and Molecular Biology, Shahjalal University of Science and Technology, Sylhet, Bangladesh. The odonates were identified with the help of keys provided by Fraser (1933, 1934, 1936), Asahina (1967), Lahiri (1987), Mitra (2002), Subramanian (2005), and Nair (2011). Odonata taxonomy and binomial names provided by Subramanian (2009) were followed except for Aristocypha Laidlaw, 1950 instead of Rhinocypha Rambur, 1942. Onychargia atrocyana Selys, 1865 was placed in the family of Platycnemididae instead of Coenagrionidae as proposed by Dijkstra et al. (2013). The family classification was followed on the basis of Subramanian (2014) and Dijkstra (2013).

\section{RESULTS}

A total of 64 species from seven families belonging to 41 genera were recorded from the study area (Tables 2,3). Among the documented odonates, 59\% (38 species) belong to Anisoptera sub-order while the rest $40 \%$ (26 species) is of Zygoptera sub-order (Table 3). Libellulidae is the predominant Anisoptera family with 32 species from 22 genera (Fig. 2, Table 3). On the other hand, Coenagrionidae is the best represented Zygoptera family with 17 species from eight genera (Fig. 2, Table 3). A maximum of 52 species was recorded from Tilagor Eco Park followed by 45 from SUST campus whereas a minimum of 10 species was sighted from Madhobpur Lake (Table 1). Crocothemis servilia Drury, 1770, Neurothemis fulvia Drury, 1773, Neurothemis intermedia Rambur, 1842 and Orthretrum sabina Drury, 1770 were sighted from all of the study locations, and can be considered the most widespread species. Crocothemis servilia Drury, 1770 and Orthretrum sabina Drury, 1770 are the most abundant species from different locations except Rajkandi Reserve Forest and Lawachara National Park where Neurothemis intermedia Rambur, 1842 was the predominant species. The present study added 45 species (24 Anisoptera and 21 Zygoptera) to the known Odonata fauna of the north-east which is now 76 species (Appendix 1). Also, five Odonata species (two Anisoptera and three Zygoptera) were newly added to the current Odonata fauna of Bangladesh. The newly recorded species are discussed along with their taxonomic status.

\section{Anax indicus Lieftinck, 1942 (Aeshnidae) (Image 1a)}

Anax is a large dragonfly genus of 29 species and distributed throughout the World (Tsuda 2000; Schorr \& Paulson 2012). Anax indicus is the second Anax species recorded from Bangladesh after Anax guttatus (Chowdhury \& Mohiuddin 2011). One Anax indicus male was sighted from the Shahjalal University of Science and Technology (SUST) campus on 16 April 2014. Previously the species was known from India, Nepal, Pakistan, Sri Lanka and Thailand (Mitra 2010). The present record extends its distribution to Bangladesh also. Anax guttatus and Anax indicus are closely related species. However, identification of the species is possible by the close comparison of the abdominal segments and anal appendages. The observed male specimen appropriately fit the description provided by Lieftinck, 1955 "The two pairs of postjugal spots are broadly fused to form a continuous band on $6,7 \& 8$, also the orange spot on 9 is clearly formed by the fusion of a very small basal and a large apical spot".

IUCN Red List status: Least Concern (Mitra 2010).

\section{Gynacantha Khasiaca MacLachlan, 1896 (Aeshnidae) (Image 1b)}

Gynacantha khasiaca is the most beautiful of the genus Gynacantha and can be distinguished easily by the great length of the inferior anal appendages (Fraser 1936). I have sighted the species on 24 October 2014 from stream associated shade of the Tilagor Eco Park. The male matches perfectly with the identification key provided by Fraser (1936) "Inferior anal appendages more than half of the length of superiors; thorax brightly grass green with two sharply defined blackish-brown stripes on each sides". Previously the species was known from India, Myanmar and Nepal. Except for the record in 1980 from Nepal, all the other records of the species are older than 70 years which may indicate the extreme rarity of the species. However, the claim cannot be consolidated due to the scanty nature of the studies and lack of expert sampling in the area. 
Table 1. Details of survey localities of the present study

\begin{tabular}{|c|c|c|c|c|c|c|}
\hline & Locality & GPS & District & Date visited & Habitat & $\begin{array}{l}\text { No. of } \\
\text { species }\end{array}$ \\
\hline 1 & Madhobpur Lake & $24^{0} 16^{\prime} 51.1^{\prime \prime} \mathrm{N} \& 91^{\circ} 49^{\prime} 1.61^{\prime \prime} \mathrm{E}$ & Maulavibazar & 24 January 2015 & $\begin{array}{l}\text { Lake associated forest } \\
\text { patches }\end{array}$ & 10 \\
\hline 3 & Rajkandi Reserve Forest & $24^{0} 15^{\prime} 25^{\prime \prime} N \& 91^{0} 54^{\prime} 47^{\prime \prime} E$ & Maulavibazar & $\begin{array}{l}6 \text { November } 2014 \\
13-14 \text { December } 2014\end{array}$ & $\begin{array}{l}\text { Semi ever-green forest } \\
\text { with streams and water } \\
\text { falls }\end{array}$ & 21 \\
\hline 4 & $\begin{array}{l}\text { Shahjalal University of } \\
\text { Science and Technology } \\
\text { (SUST) campus }\end{array}$ & $24^{0} 55^{\prime} 09^{\prime \prime} N \& 91^{\circ} 49^{\prime} 54^{\prime \prime} \mathrm{E}$ & Sylhet & $\begin{array}{l}\text { Weekly visit in the study } \\
\text { period }\end{array}$ & $\begin{array}{l}\text { Semi urban area with } \\
\text { forest patches and lakes }\end{array}$ & 45 \\
\hline 5 & Satchari National Park & $24^{\circ} 07^{\prime} 12^{\prime \prime} \mathrm{N} \& 91^{\circ} 27^{\prime} 03^{\prime \prime} \mathrm{E}$ & Habigonj & 3-5 October 2014 & Tropical evergreen forest & 13 \\
\hline 6 & Tilagor Eco Park & $24^{0} 55^{\prime} 2.3^{\prime \prime} \mathrm{N} \& 91^{\circ} 53^{\prime} 37.2^{\prime \prime} \mathrm{E}$ & Sylhet & $\begin{array}{l}\text { Biweekly visit in the } \\
\text { study period }\end{array}$ & Semi ever-green forest & 52 \\
\hline
\end{tabular}

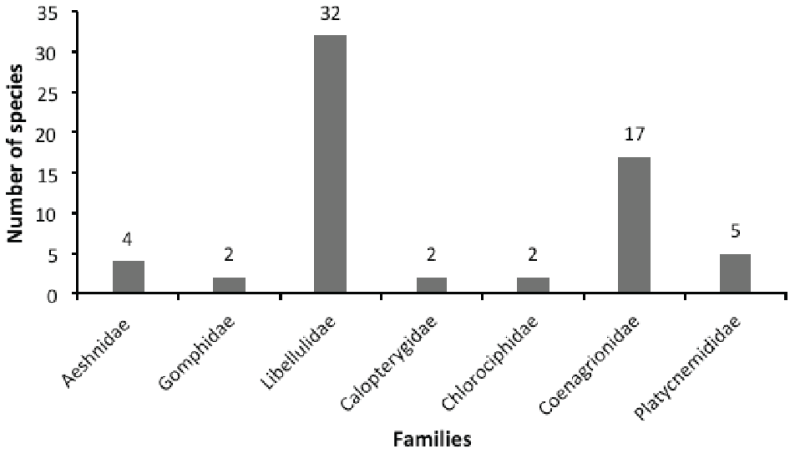

Figure 2. Number of families and their corresponding species recorded in the northeastern region of Bangladesh.

IUCN Red List status: Data Deficient (Mitra et al. 2010).

\section{Matrona nigripectus Selys, 1879 (Calopterygidae)} (Image 2a,b)

Although Matrona nigripectus was previously considered as a subspecies of Matrona basilaris, currently it is regarded as a distinct species of the sevenmembered Matrona genus (Dow 2009). The species was sighted on 6 November 2014 in a hilly stream in Rajkandi Reserve Forest. More than 10 males and three females were observed perched on the rock and shrubs associated with the stream. Previously the species were known from India, Thailand and Vietnam (Hamalainen \& Zhang 2011; Joshi \& Kunte 2014).

IUCN Red List status: Not Evaluated.

\section{Agriocnemis kalinga Nair \& Subramanian, 2014 (Coenagrionidae) (Image 2c,d)}

Agriocnemis kalinga Nair \& Subramanian, 2014 has been recently described as a new species to science from eastern India (Nair \& Subramanian 2014). The
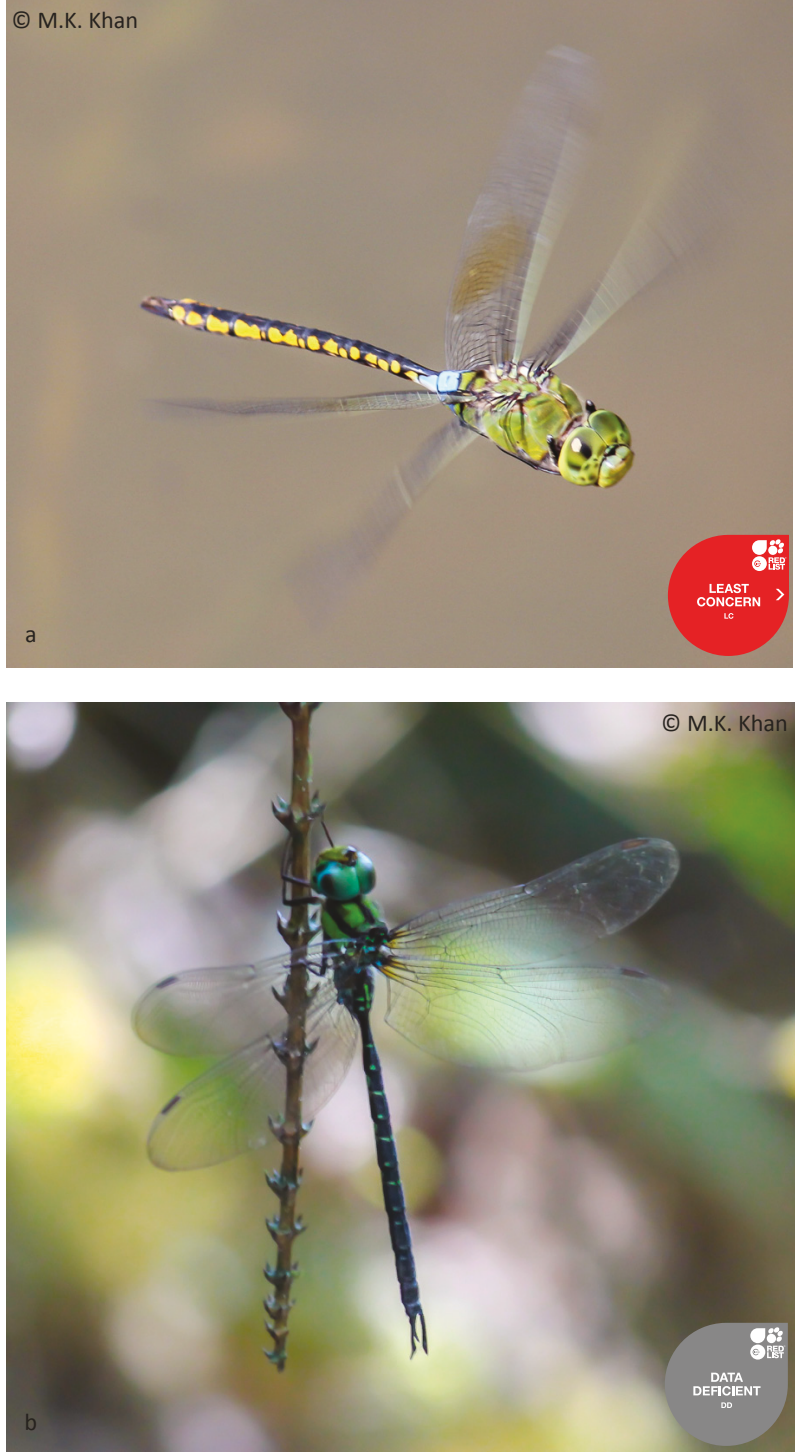

Image 1. Newly recorded Anisoptera from Bangladesh (Aeshnidae). 1a - Anax indicus Lieftinck, 1942 (male);

1b - Gynacantha khasiaca McLachlan, 1896 (male). 
Table 2. A list of the odonates recorded in the current study. Study area- 1. Lawachara National Park, 2. Madhobpur Lake,

3. Rajkandi Reserve Forest, 4. Satchari National Park, 5. Shahjalal University of Science and Technology (SUST) campus, 6. Tilagor Eco Park

\begin{tabular}{|c|c|c|c|c|c|c|c|c|}
\hline & Species name & 1 & 2 & 3 & 4 & 5 & 6 & Chowdhury \& Mohiuddin2011 \\
\hline 1 & Anax indicus Lieftinck, 1942* & & & & & + & & \\
\hline 2 & Gynacantha hyalina Selys, 1882 & & & & & + & + & \\
\hline 3 & Gynacantha khasiaca McLachlan, 1896* & & & & & & + & \\
\hline 4 & Gomphidae & & & & & & & \\
\hline 5 & Ictinogomphus rapax Rambur, 1842 & & & & & + & + & + \\
\hline \multirow[t]{2}{*}{6} & Paragomphus lineatus Selys, 1850 & & & & & + & + & \\
\hline & Libellulidae & & & & & & & \\
\hline 10 & Brachydiplax farinosa Krüger, 1902 & & & & & + & + & \\
\hline 11 & Brachydiplax sobrina Rambur, 1842 & & & & & + & + & \\
\hline 12 & Brachythemis contaminata Fabricius, 1793 & + & & & & + & + & + \\
\hline 13 & Cratilla lineata Foerster, 1903 & + & & + & + & & + & \\
\hline 14 & Crocothemis servilia Drury, 1770 & + & + & + & + & + & + & \\
\hline 15 & Diplacodes nebulosa Fabricius, 1793 & & & + & & + & + & \\
\hline 16 & Diplacodes trivialis Rambur, 1842 & + & & + & + & + & + & + \\
\hline 22 & Neurothemis tullia Drury, 1773 & & & & & + & + & \\
\hline 23 & Orthetrum chrysis Selys, 1891 & + & & + & + & + & + & + \\
\hline 24 & Orthetrum glaucum Brauer, 1865 & & & & & & + & \\
\hline 25 & Orthetrum luzonicum Brauer, 1868 & + & & & & & & \\
\hline 26 & Orthetrum pruinosum Rambur, 1842 & + & & + & + & + & + & + \\
\hline 27 & Orthetrum sabina Drury, 1770 & + & + & + & + & + & + & + \\
\hline 28 & Palpopleura sexmaculata Fabricius, 1787 & & & + & & + & + & + \\
\hline 29 & Pantala flavescens Fabricius, 1798 & & & & & + & + & \\
\hline 30 & Potamarcha congener Rambur, 1842 & & & + & & + & + & \\
\hline 31 & Rhodothemis rufa Rambur, 1842 & & & & & + & + & \\
\hline 32 & Rhyothemis variegata Linnaeus, 1763 & & & & & + & + & + \\
\hline 33 & Tholymis tillarga Fabricius, 1798 & + & & + & & + & + & + \\
\hline 34 & Tramea basilaris Kirby, 1889 & & & & & & + & \\
\hline 35 & Trithemis festiva Rambur, 1842 & & & + & & & & \\
\hline 36 & Trithemis pallidinervis Kirby, 1889 & & & & & + & & \\
\hline
\end{tabular}




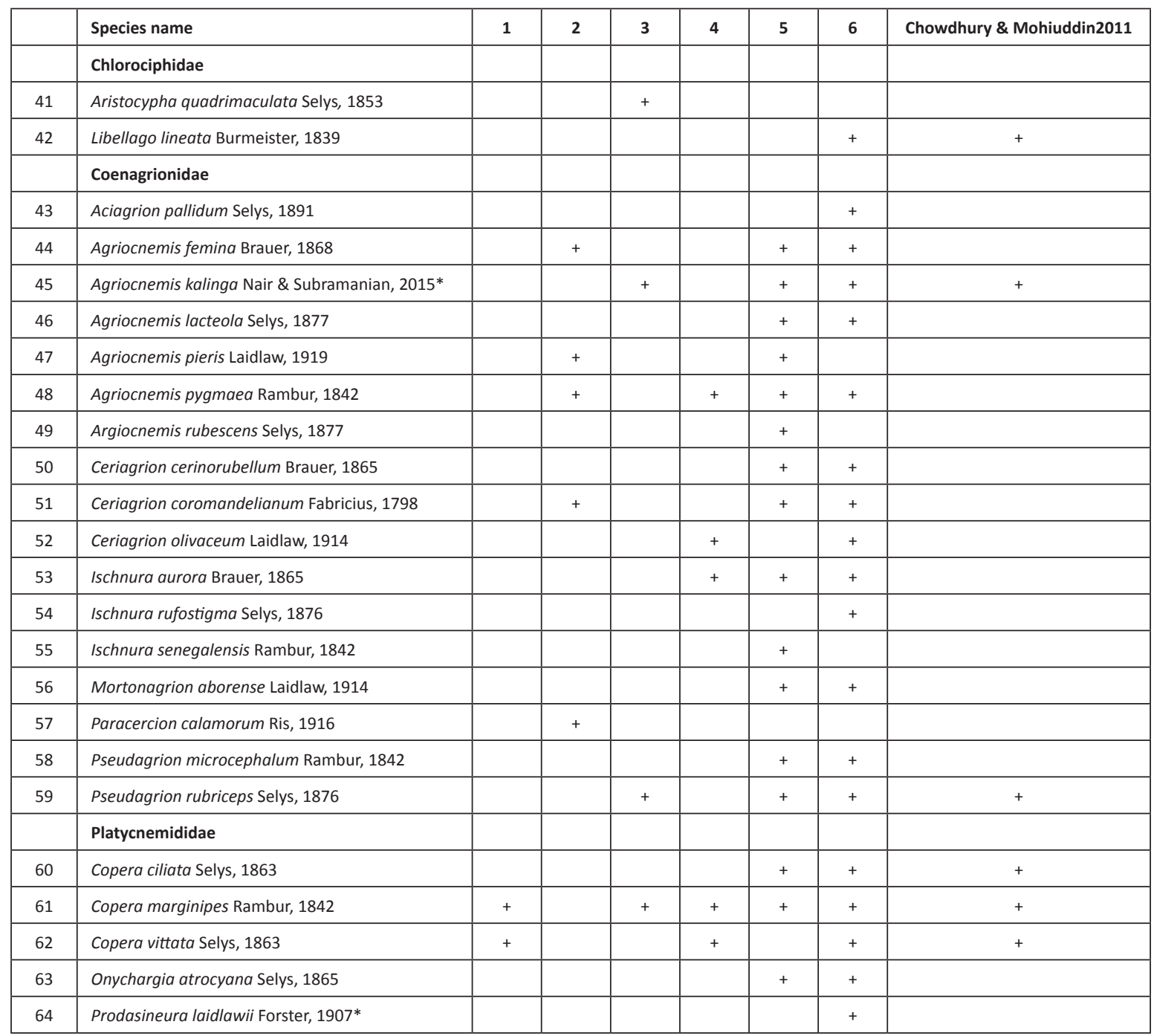

* new records for Bangladesh

current sightings from Bangladesh is the first record of the species from outside of the geographical boundary of India. The species was sighted several times from SUST campus and Tilagor Eco Park from January to October. The male is similar to Agriocnemis keralensis and can be differentiated by comparing the post ocular spot mainly while the females are apple green in color and can be distinguished easily from the Agriocnemis female.

IUCN Red List Status: Not Evaluated.

\section{Prodasineura laidlawii Foester, 1907 (Platycnemididae) (Image 2e,f)}

Prodasineura laidlawii are quiet common in the shaded region of the stream in Tilagor Eco Park. I have sighted a plethora of male individuals during the post monsoon (August-November) visits at the study site. The sightings of females were extremely rare indicating the paucity of females. The collected specimen matches perfectly with the description provided by Asahina (1993). The blue-striped species can be identified and distinguished easily from the similar species by the following feature: black abdomen with a blue longitudinal streak on segment 2; a pair of blue spot at segment 8; the dorsal side of segment 9 and 10 and superior anal appendages are azure blue. The species was previously known from Malaysia, Cambodia, Vietnam, Thailand and Myanmar (Kosterin \& Vikhrev 2009). The present record extended its distribution to further south in Bangladesh. IUCN Red List status: Least Concern (Dow 2011).

\section{Discussion}

Although regular surveys were carried out in Tilagor Eco Park and Shahjalal University of Science and Technology by covering all the seasons, studies in the other four sites were opportunistic. Hence, the present checklist needs to be updated from time to time by more 

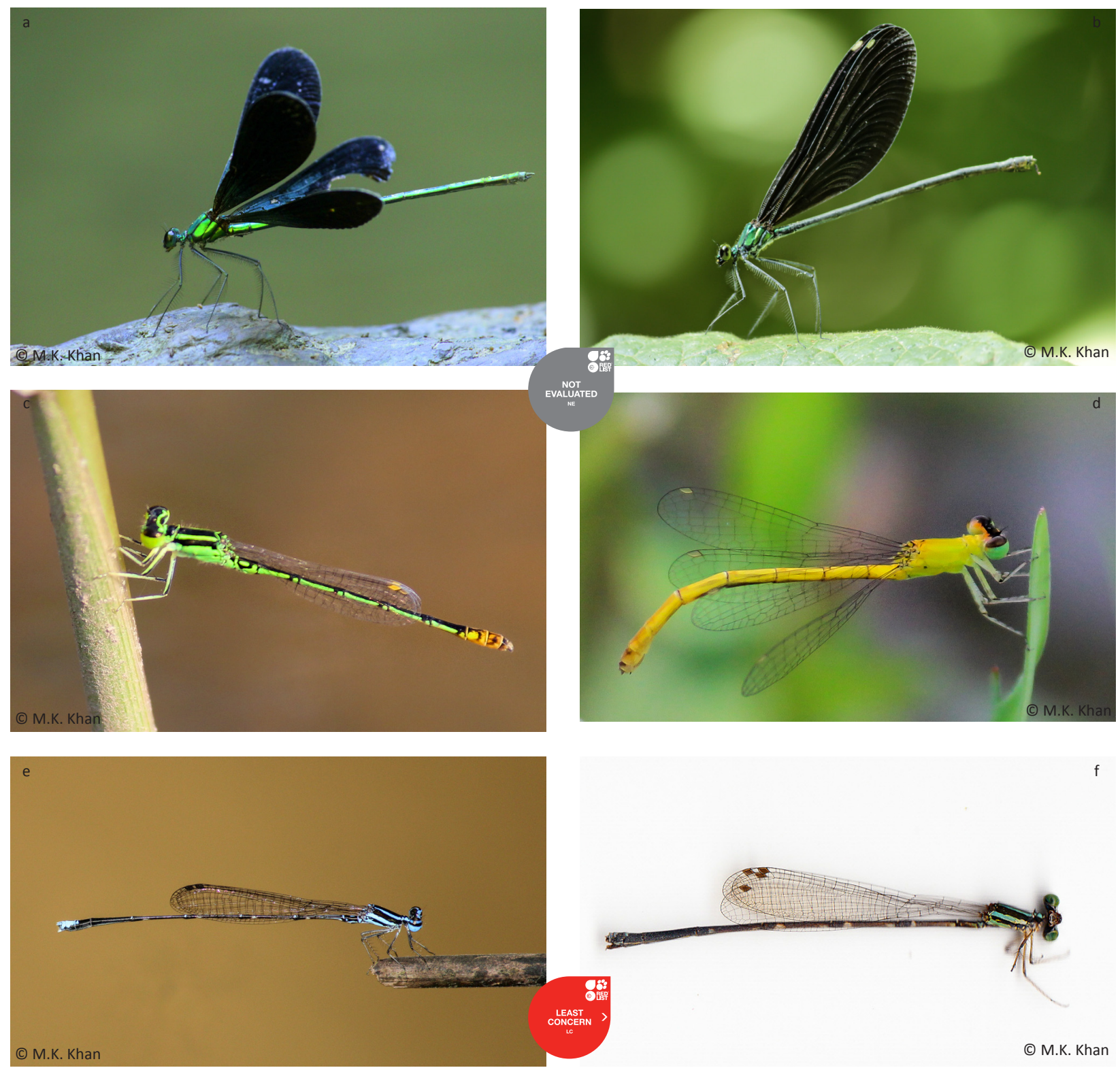

(c) M.K. Khan

Image 2. Newly recorded Zygoptera from Bangladesh (Calopterygidae, Coenagrionidae, Platycnemididae).

a - Matrona nigripectus Selys, 1879 (male); b - Matrona nigripectus Selys, 1879 (female); c - Agriocnemis kalinga Nair \& Subramanian, 2014 (male); d - Agriocnemis kalinga Nair \& Subramanian, 2014 (female); e - Prodasineura laidlawii Forster, 1907 (male); - Prodasineura laidlawii Forster, 1907 (female).

surveys particularly in the waterfalls, streams, canopy and forests of the study area. However, opportunistic studies sometimes play an important role in updating the status of many Odonata species, particularly of the cryptic species (Koparde et al. 2014). The present study added five new species to Bangladeshsi Odonata fauna, among them two were sighted during opportunistic visits. Moreover, among the 45 new regional records, six species (3 Anisoptera and 3 Zygoptera) were documented only at times of opportunistic visits which further justifies the importance of such surveys.
The present study recorded three Gynacantha species, all of them from the dark shades of the forest canopy. Due to their crepuscular nature, capturing and even photographing them was extremely difficult (Dijkstra 2005). Perhaps that is why no Gynacantha species was previously known from the study area.

Most of the recorded Libellulidae species except Hydrobasileus croceus, Orthretrum glaucum and Tramea basilaris are quiet common on SUST campus and Tilagor Eco Park and can be seen in flight throughout most of the year. Hydrobasileus croceus was sighted only once from 
Table 3. A taxonomic summary of odonates of the northeastern region of Bangladesh

\begin{tabular}{|c|c|}
\hline Sub-order Anisoptera & \\
\hline Genus & No. of species \\
\hline \multicolumn{2}{|l|}{ Aeshnidae } \\
\hline Anax & 1 \\
\hline Gynacantha & 3 \\
\hline \multicolumn{2}{|l|}{ Gomphidae } \\
\hline Ictinogomphus & 1 \\
\hline Paragomphus & 1 \\
\hline \multicolumn{2}{|l|}{ Libellulidae } \\
\hline Acisoma & 1 \\
\hline Aethriamanta & 1 \\
\hline Brachydiplax & 3 \\
\hline Brachythemis & 1 \\
\hline Cratilla & 1 \\
\hline Crocothemis & 1 \\
\hline Diplacodes & 2 \\
\hline Hydrobasileus & 1 \\
\hline Indothemis & 1 \\
\hline Lathrecista & 1 \\
\hline Neurothemis & 3 \\
\hline Orthetrum & 5 \\
\hline Palpopleura & 1 \\
\hline Pantala & 1 \\
\hline Potamarcha & 1 \\
\hline Rhodothemis & 1 \\
\hline Rhyothemis & 1 \\
\hline Tholymis & 1 \\
\hline Tramea & 1 \\
\hline Trithemis & 2 \\
\hline Urothemis & 1 \\
\hline Zyxomma & 1 \\
\hline Total genera (26) & Total species (38) \\
\hline \multicolumn{2}{|l|}{ Sub-order Zygoptera } \\
\hline \multicolumn{2}{|l|}{ Calopterygidae } \\
\hline Vestalis & 1 \\
\hline Matrona & 1 \\
\hline \multicolumn{2}{|l|}{ Chlorociphidae } \\
\hline Aristocypha & 1 \\
\hline Libellago & 1 \\
\hline \multicolumn{2}{|l|}{ Coenagrionidae } \\
\hline Aciagrion & 1 \\
\hline Agriocnemis & 5 \\
\hline Argiocnemis & 1 \\
\hline Ceriagrion & 3 \\
\hline Ischnura & 3 \\
\hline Mortonagrion & 1 \\
\hline Paracercion & 1 \\
\hline Pseudagrion & 2 \\
\hline \multicolumn{2}{|l|}{ Platycnemididae } \\
\hline Copera & 3 \\
\hline Onychargia & 1 \\
\hline Prodasineura & 1 \\
\hline Total genera (15) & Total species (26) \\
\hline
\end{tabular}

SUST campus on 28 October 2014 while Orthretrum glaucum and Tramea basilaris were observed from Tilagor Eco Park on 30 November 2014 and 20 May 2014 respectively. The lack of sightings indicates the extreme rarity of these species in the study area. On the other hand, although Indothemis limbata and Orthetrum luzonicum were sighted once from Rajkandi Reserve Forest and Lawachara National Park respectively, their status cannot be confirmed because the study did not cover the seasonal variation in those two study areas. Also Diplacodes nebulosa and Lathrecista asiatica were sighted rarely and are quiet uncommon species in the northeastern region.

Calopterygidae and Chlorociphidae are two rare families found in the study area whose distribution is restricted to streams and waterfalls as suggested by the previous study. Vestalis gracilis, was sighted from the forest canopy of Lawachara National Park and stream associated canopy of Rajkandi Reserve Forest and Tilagor Eco Park. The distribution of Matrona nigripectus and Aristocypha quadrimaculata is confined to HamHam Waterfall of the Rajkandi Reserve Forest.

Among the members of the Coenagrionidae family, Aciagrion pallidum and Ceriagrion olivaceum are extremely rare in the study area. An Aciagrion pallidum male was sighted from the canopy of Tilagor Eco Park on 2 January 2015 and a single female was recorded from the same locale on 11 January 2015. Another rare species, Ceriagrion olivaceum was observed from Satchari National Park on 3 August 2014 and from Tilagor Eco Park on 30 September 2014. The rest of the Coenagrionidae species are common in the lakes, ponds and other temporary water bodies of SUST campus and Tilagor Eco Park.

The present study reveals the diversity of Odonata in the northeastern region of Bangladesh. Moreover, the study has exposed the underexplored Odonata of the northeastern hilly streams and the richness of the habitat. Future explorations needs be carried out in the the unexplored area to update the present checklist.

\section{REFERENCES}

Asahina, S. (1967). A revision of the Asiatic species of the damselflies of the genus Ceriagrion (Odonata, Agrionidae). Japanese Journal of Zoology 15(3): 255-334, figs. 1-237

Asahina, S. (1993). A List of the Odonata from Thailand: Parts I-XXI. Bosco Offset, Bangkok, 460pp.

Begum, A., M.A. Bashar, A.K. Dutta \& L.C. Bashak (1977). A Systematic note on the Dragonflies of Dhaka City and its suburbs. Journal of Asiatic Society Bangladesh 2: 43-45.

Biswas, V., M.A. Bashar \& A. Begum (1980). On a collection of Odonata from Bagerhat District, Khulna, Bangladesh. Indian Odonatology 3: 65-66 
Butler, R.G. (2008). The significance of littoral and shoreline habitat integrity to the conservation of lacustrine damselflies (Odonata). Journal of Insect Conservation 12(1): 23-36.

Cheshire, K.I.M., L.U.Z. Boyero \& R.G. Pearson (2005). Food webs in tropical Australian streams: shredders are not scarce. Freshwater Biology 50(5): 748-769.

Chowdhury, S.H. \& M. Akhteruzzaman (1983). Dragonflies (Anisoptera, Odonata) of Chittagong University Campus, Bangladesh - Part II. Chittagong University Studies 7(I): 39-48.

Chowdhury, S.H. \& M.I. Mia (1989). Notes on some damselflies (Odonata, Zygoptera) of Chittagong University Campus - Part II. Chittagong University Studies 13: 65-70.

Chowdhury, S.H. \& M. Mohiuddin (1993). New Dragonflies from Chittagong University Campus. Bangladesh Journal of Zoology 21(2): 149-150.

Chowdhury, S.H. \& M. Mohiuddin (1994). Dragonfly Phenology - A mechanism for optimal habitat utilization. Advances in Orienta Odonatology. (Ed. V.K. Srivastava): 47-54

Chowdhury, S.H. \& M. Mohiuddin (2011). A check-list of the Odonata from the eastern region of Bangladesh with some taxonomic notes. University Journal of Zoology (Rajshahi University) 30: 61-66; http:// dx.doi.org/10.3329/ujzru.v30i0.10755

Crowley, P.H. \& D.M. Johnson (1982). Habitat and seasonality as niche axes in an odonate community. Ecology 1064-1077.

Dijkstra, K.D.B. (2005). Taxonomy and identification of the continenta African Gynacantha and Heliaeschna species (Odonata: Aeshnidae). International Journal of Odonatology 8(1): 1-168.

Dijkstra, K.D.B., V.J. Kalkman, R.A. Dow, F.R. Stokvis \& J. van To (2013). Redefining the damselfly families: the first comprehensive molecular phylogeny of Zygoptera (Odonata). Systematic Entomology 39(1): 68-96; http://dx.doi.org/ 10.1111/syen.12035

Dow, R.A. (2009). Matrona basilaris. The IUCN Red List of Threatened Species. Version 2014.3. <www.iucnredlist.org>. Downloaded on 01 February 2015.

Dow, R.A. (2011). Prodasineura laidlawii. The IUCN Red List of Threatened Species. Version 2014.3. <www.iucnredlist.org>. Downloaded on 01 February 2015.

Fraser, F.C. (1933, 1934, 1936). The Fauna of British India including Ceylon and Burma: Odonata, Volumes 1, 2 \& 3. Taylor and Francis Ltd., London, 423pp, 398pp, 461pp.

Hamalainen, M., X. Yu \& H. Zhang (2011). Descriptions of Matrona oreades sp. nov. and Matrona corephaea sp. nov. from China (Odonata: Calopterygidae). Zootaxa 2830: 20-28.

Joshi, S. \& K. Kunte (2014). Dragonflies and damselflies (Insecta: Odonata) of Nagaland, with an addition to the Indian odonate fauna. Journal of Threatened Taxa 6(11): 6458-6472; http://dx.doi. org/10.11609/JoTT.o3911.6458-72

Khan, M.K. (2015). Gynacantha subinterrupta Rambur, 1842: an addition to the odonates (Insecta: Odonata: Aeshnidae) of Bangladesh. Journal of Threatened Taxa 7(10): 7704-7705; http:// dx.doi.org/10.11609/JoTT.o4276.7704-5
Koparde, P., P. Mhaske \& A. Patwardhan (2014). New records of dragonflies and damselflies (Insecta: Odonata) from the Western Ghats of Maharashtra, India. Journal of Threatened Taxa 6(5): 57445754; http://dx.doi.org/10.11609/JoTT.03402.5744-54

Kosterin, O.E. \& N.E. Vikhrev (2009). Some new provincial records of Odonata made in Thailand in 2007-2009 and a new record from Vietnam. Agrion 13(2): 75-79.

Lahiri, A.R. (1987). Studies on the odonate fauna of Meghalaya. Records Zoological Survey India Occasional Paper no. 99: 1-402

Mitra, T.R. (2002). Geographical distributin of Odonata (Insecta) of Eastern India. Memoirs of Zoological Survey of India 19(9): 208.

Mitra, A. (2010). Anax indicus. The IUCN Red List of Threatened Species. Version 2014.3. <www.iucnredlist.org>. Downloaded on 20 March 2015.

Mitra, A., R. Babu \& R.A. Dow (2010). Gynacantha khasiaca. The IUCN Red List of Threatened Species. Version 2014.3. <www.iucnredlist. org>. Downloaded on 31 January 2015.

Nair, M.V. (2011). Dragonflies \& Damselflies of Orissa and Eastern India. Wildlife Organization, Forest \& Environment Department, Government of Orissa, 252pp.

Nair, M.V. \& K.A. Subramanian (2015). A new species of Agriocnemis Selys, 1869 (Zygoptera: Coenagrionidae) from eastern India with redescription of Agriocnemis keralensis Peter, 1981. Records of the Zoological Survey of India 114(part-4): 669-679 (2014).

Nomura, S. \& M.Z. Alam (1995). A list of dragonflies collected in Bangladesh. ESAKIA 35: 135-140.

Schorr, M. \& D. Paulson (2012). World Odonata list. http://www. pugetsound.edu/academics/academic-resources/slater-museum/ biodiversity-resources/dragonflies/world-odonata-list/. Accessed on April 2015.

Silva, D.P., P. De Marco \& D.C. Resende (2010). Adult odonate abundance and community assemblage measures as indicators of stream ecological integrity: a case study. Ecological Indicators 10: 744-752; htt://dx.doi.org/10.1016/j.ecolind.2009.12.004

Subramanian, K.A. (2005). Dragonflies and Damselflies of Peninsular India - A Field Guide. [Series Editor: Madhav Gadgil]. Published under the Project Lifescape Series. Indian Academy of Sciences, Banglore, India, 118pp.

Subramanian, K.A. (2009). A Checklist of Odonata of India. Zoological Survey of India, 36pp.

Subramanian, K.A. (2014). A Checklist of Odonata of India. Zoological Survey of India, Kolkata, 31pp.

Tsuda, S. (2000). A Distributional List of World Odonata. Osaka, Japan, 430pp.

Vick, G.S. (2002). Preliminary biodiversity assessment of odonate fauna of the Takamanda Forest Reserve, Camerooon. IDF-Report 4: $1-10$. 
Appendix 1. A checklist of the Odonata fauna of the northeastern region of Bangladesh. The newly added species to the Bangladeshi Odonata fauna are shown in astericks (*). Species recorded by Chowdhury \& Mohiuddin (2011) but not in the present study are shown in bold.

\begin{tabular}{|c|c|}
\hline & Species name \\
\hline & Aeshnidae \\
\hline 1 & Anax indicus Lieftinck, 1942* \\
\hline 2 & Gynacantha hyalina Selys, $1882^{*}$ \\
\hline 3 & Gynacantha khasiaca McLachlan, 1896* \\
\hline \multirow[t]{2}{*}{4} & Gynacantha subinterrupta Rambur, 1842* \\
\hline & Gomphidae \\
\hline 5 & Ictinogomphus rapax Rambur, 1842 \\
\hline 6 & Paragomphus lineatus Selys, 1850 \\
\hline \multirow[t]{2}{*}{7} & Macrogomphus robustus Selys, 1854 \\
\hline & Libellulidae \\
\hline 8 & Acisoma panorpoides Rambur, 1842 \\
\hline 9 & Aethriamanta brevipennis Rambur, 1842 \\
\hline 10 & Brachydiplax chalybea Brauer, 1868 \\
\hline 11 & Brachydiplax farinosa Krüger, 1902 \\
\hline 12 & Brachydiplax sobrina Rambur, 1842 \\
\hline 13 & Brachythemis contaminata Fabricius, 1793 \\
\hline 14 & Cratilla lineata Foerster, 1903 \\
\hline 15 & Crocothemis servilia Drury, 1770 \\
\hline 16 & Diplacodes nebulosa Fabricius, 1793 \\
\hline 17 & Diplacodes trivialis Rambur, 1842 \\
\hline 18 & Hydrobasileus croceus Brauer, 1867 \\
\hline 19 & Indothemis limbata Selys, 1891 \\
\hline 20 & Lathrecista asiatica Fabricius, 1798 \\
\hline 21 & Neurothemis fulvia Drury, 1773 \\
\hline 22 & Neurothemis intermedia Rambur, 1842 \\
\hline 23 & Neurothemis tullia Drury, 1773 \\
\hline 24 & Orthetrum cancellatum Linnaeus, 1758 \\
\hline 25 & Orthetrum chrysis Selys, 1891 \\
\hline 26 & Orthetrum glaucum Brauer, 1865 \\
\hline 27 & Orthetrum luzonicum Brauer, 1868 \\
\hline 28 & Orthetrum pruinosum Rambur, 1842 \\
\hline 29 & Orthetrum sabina Drury, 1770 \\
\hline 30 & Palpopleura sexmaculata Fabricius, 1787 \\
\hline 31 & Pantala flavescens Fabricius, 1798 \\
\hline 32 & Potamarcha congener Rambur, 1842 \\
\hline 33 & Rhodothemis rufa Rambur, 1842 \\
\hline 34 & Rhyothemis variegata Linnaeus, 1763 \\
\hline 35 & Tholymis tillarga Fabricius, 1798 \\
\hline 36 & Tramea basilaris Kirby, 1889 \\
\hline 37 & Trithemis aurora Burmeister, 1839 \\
\hline 38 & Trithemis festiva Rambur, 1842 \\
\hline 39 & Trithemis pallidinervis Kirby, 1889 \\
\hline
\end{tabular}

\begin{tabular}{|c|c|}
\hline 40 & Urothemis signata Rambur, 1842 \\
\hline \multirow[t]{2}{*}{41} & Zyxomma petiolatum Rambur, 1842 \\
\hline & Calopterygidae \\
\hline 42 & $\begin{array}{l}\text { Allophaea ochracea Selys, } 1859 \text { syn. Allophaea brunnea Selys, } \\
1879\end{array}$ \\
\hline 43 & Vestalis gracilis Rambur, 1842 \\
\hline 44 & Vestalis smaragdina Selys, 1853 \\
\hline \multirow[t]{2}{*}{45} & Matrona nigripectus Selys, 1879* \\
\hline & Chlorociphidae \\
\hline 46 & Aristocypha quadrimaculata Selys, 1853 \\
\hline \multirow[t]{2}{*}{47} & Libellago lineata Burmeister, 1839 \\
\hline & Coenagrionidae \\
\hline 48 & Aciagrion pallidum Selys, 1891 \\
\hline 49 & Agriocnemis femina Brauer, 1868 \\
\hline 50 & Agriocnemis Kalinga Nair \& Subramanian, 2015 \\
\hline 51 & Agriocnemis lacteola Selys, 1877 \\
\hline 52 & Agriocnemis naia Fraser, 1923 \\
\hline 53 & Agriocnemis pieris Laidlaw, 1919 \\
\hline 54 & Agriocnemis pygmaea Rambur, 1842 \\
\hline 55 & Argiocnemis rubescens Selys, 1877 \\
\hline 56 & Ceriagrion cerinorubellum Brauer, 1865 \\
\hline 57 & Ceriagrion coromandelianum Fabricius, 1798 \\
\hline 58 & Ceriagrion olivaceum Laidlaw, 1914 \\
\hline 59 & Ischnura aurora Brauer, 1865 \\
\hline 60 & Ischnura rufostigma Selys, 1876 \\
\hline 61 & Ischnura senegalensis Rambur, 1842 \\
\hline 62 & Mortonagrion aborense Laidlaw, 1914 \\
\hline 63 & Paracercion calamorum Ris, 1916 \\
\hline 64 & Pseudagrion microcephalum Rambur, 1842 \\
\hline \multirow[t]{2}{*}{65} & Pseudagrion rubriceps Selys, 1876 \\
\hline & Platycnemididae \\
\hline 66 & Coeliccia bimaculata Laidlaw, 1914 \\
\hline 67 & Coeliccia didyma Selys, 1863 \\
\hline 68 & Calicnemia pulverulans Selys, 1886 \\
\hline 69 & Calicnemia eximia Selys, 1863 \\
\hline 70 & Copera ciliata Selys, 1863 \\
\hline 71 & Copera marginipes Rambur, 1842 \\
\hline 72 & Copera vittata Selys, 1863 \\
\hline 73 & Onychargia atrocyana Selys, 1865 \\
\hline 74 & Prodasineura laidlawii Forster, 1907* \\
\hline 75 & $\begin{array}{l}\text { Caconeura botti Fraser, } 1922 \text { syn. Prodasineura collaris Selys, } \\
1860\end{array}$ \\
\hline 76 & $\begin{array}{l}\text { Disparoneura campioni Fraser, } 1922 \text { syn. Elattoneura campioni } \\
\text { Fraser, } 1922\end{array}$ \\
\hline
\end{tabular}

